\title{
Fenntarthatósági szempontok érvényesülése a szerzői jogban
}

\author{
Sustainability in Copyright Law
}

\begin{abstract}
ABSZTRAKT
A tanulmány célja, hogy áttekintést adjon a szerzői jog 21. századi útkereséséről, a szerzői jogi fenntarthatóság megvalósítására tett európai és magyar törekvésekről a fenntarthatóság szerzőijog-specifikus vonatkozásain keresztül, és összegezze a témában már elért jogharmonizációs eredményeket, valamint felhívja a figyelmet a még el nem ért, de kívánatos célokra. A témát a kultúra-gazdaságtani szempontból bemutatott kulturális fenntarthatóság felöl közelíti az írás. A fő témát először a szerzői jog egyensúly-keresésének történeti és jelenkori vonatkozásai segítségével mutatja be. Ezt követően a szerzői jog filozófiai, alapjogi hátterének változásait, jelenlegi helyzetét tekinti át. A szerzői vagyoni jogok és személyhez füződő jogok dinamizmusának elemzésével a tanulmány rávilágít a szerzői jogi jogosultságok párhuzamos érvényesülésének szükségességére. A szerzői jog versenyképességének vizsgálata arra irányul, hogy a versenyképesség és a fenntarthatóság egymástól elválaszthatatlan voltát kiemelje, és hangsúlyozza, hogy ezek fejlődése csak egymásra tekintettel elképzelhető.
\end{abstract}

Kulcsszavak: kulturális fenntarthatóság, szerzői jogi egyensúly, európai szerzői jogi jogharmonizáció, szerzői vagyoni jogok és személyhez füződő jogok dinamizmusa, fenntartható jogdíjak, szerzői jog versenyképessége

\begin{abstract}
The aim of the paper is to give an overview of the pathfinding process of the copyright law, and of the European and Hungarian endeavors in favour of the sustainability of the copyright law via the copyright specific aspects of sustainability. It then aims to summarize the achievements of the harmonization process and draw attention to the goals to be achieved. The topic is approached from a cultural economic perspective. The main topic is described via historical and current aspects of the balance search of copyright law. the paper reviews the background of the development and current situation of copyright law from the point of view of philosophy and fundamental rights. With the analysis of the dynamism of economic and moral rights the paper outlines the necessity of parallelism of the two parts of copyright law. The examination of competitiveness of copyright law tends to highlight the inseparability of competitiveness and sustainability and emphasizes their development as being interlinked.
\end{abstract}

Keywords: cultural sustainability, balance in copyright law, harmonization process of European copyright law, dynamism of property rights and individual rights in copyright law, sustainable royalties, competitiveness of copyright law

* Dr. Tomasovszky Edit, doktorjelölt, Debreceni Egyetem Marton Géza Állam- és Jogtudományi Doktori Iskola; e-mail: tomasovszky.edit@gmail.com. 
A fenntarthatóság nem csupán egy divatos fogalom. Tény, hogy egyre több területen ismerik fel a fenntarthatóság jelentőségét, és fogalmaznak meg ilyen irányú törekvéseket, de ez a tendencia nem véletlen és nem is önmagáért való. A korábban bebetonozottnak hitt elvek, filozófiai elméletek némelyike a 21. században már nem állja meg a helyét maradéktalanul, a technikai és az azt követő társadalmi-gazdasági fejlődés következtében újabb elvekhez kell igazodnunk, amelyek közül az egyik legfontosabb, hogy a szinte követhetetlenül gyors változások közepette mégis találjunk valami állandóságot, valami olyan bázist, amelyet hosszú távon követhetünk.

Napjainkban minden eddiginél nagyobb szerepet kap a jövő - ezzel párhuzamosan a jövőkutatás, klímakutatás igyekszik tudományos alapokon elörevetíteni a várható tendenciákat. A társadalom- és gazdaságtudományok sem elégedhetnek meg többé a jelen folyamatainak elemzésével, hanem egyre pontosabban akarják látni a jövő eseményeit, hogy azokra a lehető legnagyobb ráhatásuk legyen a jelenben. A fenntarthatóság elve a múlt tapasztalatainak, hibáinak felismerése mellett a jövőre fókuszálva igyekszik a jelenben hatékonyan irányítani a társadalmi-gazdasági és nem másodlagosan a kulturális folyamatokat, józan keretek között tartani a végtelennek tűnő növekedést a különböző területeken. A szerzői jog sem öncélúan törekszik a fenntarthatóságra, a versenyképességre. A szellemi termékek, az innováció, az alkotófolyamat eredménye a gazdaság része, így a szerzői jog minősége hatással van a gazdaság fejlődésére.

A tanulmány arra tesz kísérletet, hogy a szerzői jogi fenntarthatóság legfontosabb aspektusait azonosítsa, majd ezeket áttekintve, elemezve képet nyújtson arról, hogyan képes a szerzői jog a 21. századi igényeknek megfelelni, és hogyan törekszik egy új, hosszabb távon is fenntartható egyensúly kialakítására.

A témát a kulturális fenntarthatóság fogalma felől közelítem meg. Ezt követően felvázolom a szerzői jog egyensúlyának szerepét, az egyensúly történeti eltolódásait, majd a jelenkori törekvéseket, amelyek ezen egyensúly visszaállítására irányulnak. Ennek keretében kitérek a szerzői jog filozófiai hátterének változásaira, a személyhez füződő és vagyoni jogok dinamikus kapcsolatára, végül pedig a szerzői jog versenyképességi szempontú vizsgálatára.

A nemzetközi, az európai uniós és a magyar szerzői jogi szabályozások kölcsönhatásai okán mindhárom szinten vizsgálom a fenntarthatóság szempontjainak érvényesülését, érvényesítésének lehetőségeit.

\section{A kulturális fenntarthatóság fogalma}

A Brundtland-jelentés 1987-ben a következőképpen határozta meg a fenntartható fejlődés fogalmát: „A fenntartható fejlődés olyan fejlődés, amely kielégíti a jelen szükségleteit anélkül, hogy veszélyeztetné a jövő nemzedékek esélyét arra, hogy ők is kielégíthessék szükségleteiket."

\footnotetext{
${ }^{1}$ Közös jövőnk c. jelentés, ENSZ Környezet és Fejlődés Világbizottsága (Brundtland-bizottság), 1987, http:// www.un-documents.net/our-common-future.pdf; 41. (2020. 11. 20.).
} 
Akkoriban a fenntarthatóság három - a szociális, a gazdasági és a környezeti pillérét különböztették meg, ma már beszélhetünk társadalmi és kulturális fenntarthatóságról is. A Brundtland-jelentés óta széles körben elterjedt fenntartható fejlődés fogalma nem tekinthető azonosnak a kultúra, és azon belül is a szellemi tulajdon körében használt fenntarthatóság fogalmával. A fenntarthatóságra gondolva egyesek megállnak az ember és a természet kapcsolatánál, mások ennél tovább mennek, és azt mondják, hogy maga a fenntarthatóság is kulturális jelenség, hiszen mint elv vagy célkitüzés az emberiség kultúrája által előidézett problémákra adott önreflexióként értelmezhető. ${ }^{2}$

Mások a fenntarthatóságot a kultúra terén adaptációs technikaként értelmezik, olyan módszerként, amely a változásmenedzsment alapját is képezi: azt feltételezi, hogy az emberiség nem meríti ki az összes kognitív erőforrását (amely tulajdonképpen a kulturális öröksége). A változás pedig abban áll (és ez visszakapcsolódik a kultúrához), hogy ezt az értéket kell a nevelés és oktatás során átadni az újabb generációknak, így biztosítható egyfajta kulturális evolúció és a társadalmi kreativitás evolúciója. Tehát összességében itt a kultúra az új kihívások megválaszolásához rendelkezésre álló erőforrásként jelenik meg. ${ }^{3}$

A fenntarthatóság fogalmának használata a kultúra területén ma már általános, és egyre több, kultúrához kapcsolódó részterület veszi át. Egy relatíve fiatal tudományág, a kultúra-gazdaságtan a kultúra, a művészetek közgazdaságtani vonatkozásaival foglalkozik, és ennek keretei között a kultúra és a kulturális iparágak fenntarthatóságát illetően is megfogalmaz alapelveket, elvárásokat, a jövő érdekében a jelenben megteendő politikai-gazdasági intézkedéseket.

A közgazdász David Throsby nevéhez köthető a kulturális fenntartható fejlődés koncepciójának kidolgozása, amely mind a kulturális ipar, mind a társadalmi értelemben vett kultúra területét lefedi. Meghatározta a jövő generációinak növekedését is biztosító kritériumokat, amelyek reményei szerint fokozzák a kultúra és a gazdaság közötti kommunikációt és elismerést: ${ }^{4}$ az anyagi és nem anyagi jólét növekedése, amely a gazdasági, szociális és kulturális erőforrások közötti egyensúlyon alapul; generációk közötti méltányosság és a kulturális tőke fenntartása, amely által a jelen generációja kifejezheti felelősségét a jövő generációi felé; a jelen generációján belüli méltányosság, amely a kulturális erőforrások fair módon történő elosztására épül; az összefüggések felismerése, azaz, a politikának meg kell értenie, hogy a gazdasági, kulturális és egyéb tényezők kölcsönösen egymásra utaltak egy komplex rendszerben.

Az ENSZ Közgyűlése által 2015-ben elfogadott Agenda 2030 Fenntartható Fejlődési Keretrendszer tizenhét területen fogalmazott meg fenntartható fejlődési célokat (Sustainable Development Goals - SDG), tulajdonképpen egy új globális mércét állítva fel a fejlődés tekintetében. A fő célkitüzések a szegénység, az egyenlőtlenség

${ }^{2}$ FÉsŰ József György-NAGY Mihály: Kultúra és fenntarthatóság. Stratégiai tervezési füzetek IV. Nemzeti Kulturális Örökség Minisztériuma, KultúrPont Iroda, 2005, 11. https://docplayer.hu/2673380-Pont-a-kulturaert-kulturaes-fenntarthatosag-strategiai-tervezesi-fuzetek-iv-fesu-jozsef-gyorgy-dr-nagy-mihaly.html (2020. 05. 22.).

${ }^{3}$ FÉSÜ-NAGY: i. m., 11.

${ }^{4}$ Throsby, David: Culture, Economics and Sustainability. Journal of Cultural Economics, 1995/3, 199-206. (https://doi.org/10.1007/BF01074049). 
és igazságtalanság, valamint a klímaváltozás hatékony kezelése. Ezen főbb célokra fókuszálva azonban egy sor egyéb területen is cselekvésre van szükség, így a gazdasági növekedés és jólét kérdésében, az egészségügyi, szociális és oktatási szükségletek tekintetében és a környezetvédelem körében is politikai támogatást vár el az államoktól, a területek sokféleségéböl következően komplex szemléletmóddal.

Bár annak meghatározása, hogy mit értünk a kultúra fogalma alatt, egy önáló tanulmányt is megérne, annak szúkebb és tágabb értelmezésével a fenntartható fejlődés kulturális vonatkozásait sokkal konkrétabban meg lehet határozni, ahogyan azt Sazonova is megteszi. ${ }^{5}$ Mint e szerző rámutat, a fenntarthatóság kulturális dimenziója biztosítja, hogy a témáról való diskurzusba szélesebb körben lehessen bevonni az embereket (szemben azzal, hogy korábban szinte csak szakértők, politikusok lehettek részesei a vitáknak a fenntarthatóságot érintő témákban). Azonban a kulturális dimenzió bevonása nem csupán azt jelenti, hogy múvészeti alkotásokkal felhívjuk a figyelmet olyan fontos témákra, mint a klímaváltozás vagy a gazdasági problémák, hanem - ahogyan az UNESCO Jelentése ${ }^{6}$ is fogalmaz -, minden közpolitikának része kell, hogy legyen a kulturális perspektíva, hogy a fenntartható fejlődés folyamatainak „lelke” is legyen. Sazonova is hangsúlyozza, hogy a kulturális aspektusok beépítése azt jelenti, hogy a közpolitikák tervezése során alkalmazzuk a művészet föbb alapelveit, az interkulturális párbeszédet, és tekintettel vagyunk a kulturális sokszínüségre. ${ }^{7}$

A kulturális sokszínűség jelentőségét igazolja több nemzetközi dokumentum is, így az UNESCO 2001. évi közgyűlésén elfogadott Egyetemes Nyilatkozat a Kulturális Sokszínűségről, és az abban megfogalmazott elvek mentén, szintén az UNESCO égisze alatt 2005-ben létrejött Egyezmény a kulturális kifejezések sokszínűségének védelméről és előmozdításáról. Az Egyezmény a kulturális kivételek megerősítésével a kulturális szuverenitás megóvására törekszik. ${ }^{8}$

A kulturális sokféleség, a kulturális szuverenitás és a nemzeti identitás az európai gondolkodásban is fontos szereppel bíró kérdéskör; mára egyértelművé vált, hogy a piaci verseny szempontjainak érvényesítése mellett az Európai Unió számára az jelent versenyelőnyt, ha a jelenlévő kulturális sokszínűséget megőrzi, és uniformizálás helyett a tagállamok mint nemzetállamok kulturális hagyományaira épít, a tagállamok szoros szövetségeként müködik. ${ }^{9}$ Kulturális vonatkozásban ez a megközelítés biztosíthatja alapvetően a fenntarthatóságot Európa számára.

\footnotetext{
${ }^{5}$ Sazonova, Lilia: Cultural Aspects of Sustainable Development. Glimpses of the Ladies' Market, Friedrich Ebert Stiftung Analyses, 2014. https://library.fes.de/pdf-files/bueros/sofia/10911.pdf (2020. 08. 15.).

${ }^{6}$ Culture and sustainable development: examples of institutional innovation and proposal of a new cultural policy profile, in the framework of the process "Towards a new cultural policy profile." UNESCO, 1 September 2009, 6. - A jelentés a kulturális fenntarthatóságot a fenntarthatóság negyedik pilléreként kezeli. http:// www.agenda21 culture.net/index.php?option=com_content\&view=article\&id=87\%3Areport-4-culture-andsustainable-development-examples-of-institutional-innovationand-proposal-of-a-new-cultural-policy-profile\& catid=58\&ltemid=57\&lang=bg (2020. 11. 25.).

7 SAZONOVA: i. m., 7.

${ }^{8}$ FICSOR Mihály: A szerzői jog és a kulturális sokszínüség védelme. In: Cseporán Zsolt (szerk.): Az alkotás szabadsága és a szerzői jog metszéspontjai. MMA MMKI, Budapest, 2016, 77-80.

${ }^{9}$ FICSOR (2016): i. m., 90.
} 
Az Európai Unió Szerződéseiben is megjelennek ezek a szempontok. Az EUMSz 6. cikke pontosan körülhatárolja, hogy az EU „a tagállamok intézkedéseit támogató, összehangoló vagy kiegészítő intézkedések végrehajtására” rendelkezik hatáskörrel a c) pontban meghatározott kultúra területén. Ezen pont és a 2. cikk (5) bekezdés alapján az EU nem fogadhat el a területen a tagállamok rendelkezéseinek harmonizációját célzó vagy azt eredményező szabályozást, nincs sem kizárólagos, sem megosztott hatásköre. Az EUMSz 167. cikke megerősíti a tagállamok kulturális szuverenitását. Az EUSz 4. cikke szól a nemzeti identitás tiszteletben tartásáról. Az Alapjogi Charta preambuluma is hangsúlyozza a kulturális sokféleségnek és a tagállamok nemzeti identitásának tiszteletben tartását.

Az Európai Bizottság Zöld Könyve a kulturális és kreatív iparágak potenciáljának felszabadításáról kiemeli, hogy jelentős társadalmi és gazdasági potenciál rejlik ezen iparágakban. A kulturális és kreatív iparágak a tudástársadalom gazdasági vonatkozását képezik. A tudástársadalom a tudomány és a technológiák összefonódásából tevődik össze. A kultúra, a múvészet termékeinek (az alkotásoknak) a nagyközönséghez való jutásában is jelentős szerepe van a technológiának. ${ }^{10}$

Fentiek alapján jól látható, hogy nemzetközi szinten már elörehaladott stádiumban van a kultúra és a fenntarthatóság fogalmának összekapcsolása, a fenntartható kultúra iránti elkötelezettség. A nemzetközi tendenciák alapján Magyarországon is észlelhető már ilyen irányú törekvés. Az Alaptörvény Nemzeti Hitvallás c. fejezetében a kultúra és a fenntarthatóság a következőképpen fonódik össze: „Vállaljuk, hogy örökségünket, egyedülálló nyelvünket, a magyar kultúrát, a magyarországi nemzetiségek nyelvét és kultúráját, a Kárpát-medence természet adta és ember alkotta értékeit ápoljuk és megóvjuk. Felelősséget viselünk utódainkért, ezért anyagi, szellemi és természeti erőforrásaink gondos használatával védelmezzük az utánunk jövő nemzedékek életfeltételeit."

Hogyan alkalmazható ezek után a fenntarthatóság a kultúra jogi hátterének jelentős részét kitevő szerzői jogban?

\section{Fenntarthatóság a szerzői jogban}

Az információs és tudástársadalom és a fenntarthatóság kihívásai a szerzői jog területét is nagyban érintik, itt is jelentős szemléletváltásra van (lenne) szükség. A kultúra, a mủvészet és a szerzői jog kapcsolata ugyanis egymástól elválaszthatatlan, ezek egymással kölcsönhatásban müködnek. ${ }^{11}$

Szerzői jogi törvényünk preambuluma a következőképpen foglalja össze a kihívásokat, amelyekkel a szerzői jog napjainkban szembesül: „A technikai fejlődéssel lépést tartó, korszerü szerzői jogi szabályozás meghatározó szerepet tölt be a szellemi alkotás ösztönzésében, a nemzeti és az egyetemes kultúra értékeinek

10 TATTAY Levente: A szerzői jog versenyképességre gyakorolt hatása az Európai Unióban. Iparjogvédelmi és Szerzői Jogi Szemle, 2015/4, 18-25.

11 SÁPI Edit: Vázlat a kultúra és a szerzői jog kölcsönhatásáról, különös tekintettel a színházművészet szerzői jogi vetületére. Jogelméleti Szemle, 2017/4, 132. 
megóvásában; egyensúlyt teremt és tart fenn a szerzők és más jogosultak, valamint a felhasználók és a széles közönség érdekei között, tekintettel az oktatás, a müvelődés, a tudományos kutatás és a szabad információhoz jutás igényeire is; gondoskodik továbbá a szerzői jog és a kapcsolódó jogok széles körü, hatékony érvényesüléséről." "12

A szerzői jog a fenntarthatóság szempontjából a fentiek alapján is többrétű kihívással áll szemben: az alkotófolyamatok ösztönzése az újabb technológiai vívmányok következtében újabb módszereket kíván, miközben a szerzői jog mindenkori feladata a szellemi és kulturális értékek megőrzése, a szerzői jog által érintett különböző érdekcsoportok érdekei közötti egyensúly fenntartása mellett, a kultúra területét lefedő alapvető emberi jogok érvényesülésének biztosításával.

A szerzői jog teljes története során a különböző érdekek közötti egyensúlyra törekedett és erre törekszik ma is. E körben vizsgálni kell, hogyan küzd meg azzal a feladattal, hogy egyrészt kellő mértékü ösztönzést nyújtson a szerzők számára, másrészt a felhasználók számára az információhoz, tudáshoz való hozzáférést biztosítsa, emellett pedig a harmadik érdekcsoportnak, a közérdeknek is megfeleljen. A szerzői jog korlátai, elsősorban a szabad felhasználási módok áttekintésével kapunk választ a fenti kérdésre.

A szerzői jog filozófiai hátterének változását, 21. századivá válásának folyamatát követve egy másik aspektusból nézhetünk rá a jogi kihívásokra.

Végül a szerzői jogi jogosultságok két csoportjának, a vagyoni és a személyhez füződő jogok szerepének, azok szerzői jogban elfoglalt helyének tanulmányozásával még közelebbi képet kapunk a szerzői jog dilemmáiról. Ennek keretében a legfontosabb szempont a harmonizáció szükségességének és kívánt szintjének a vizsgálata.

A szellemi tulajdon tárgyai a tulajdon más tárgyaival szemben nem versengő közjavak, mindenki által egyszerre hozzáférhetők (ubikvitás). Ahogy Thomas Jefferson fogalmazott: „Akinek ötletet adok, annak tudása úgy nö, hogy közben az enyém nem csökken; mint ahogyan nem alszik el az én gyertyám, ha azzal más meggyújtja a sajátját."13 Ebből az alaptézisből kiindulva kell meghatározni, hogy a szerzői jogi oltalom hogyan képes ösztönözni a kreativitást és előmozdítani a tudáshoz való hozzáférést.

\section{1. Érdekek egyensúlya}

Az egyensúly és az arra való törekvés hagyományosan a szerzői jog alapvető múködési elve. A szerzői jog története során korábban két oldal, a szerzők és a felhasználók érdekei, jogosultságai között igyekezett egyensúlyt teremteni. Ehhez kapcsolódik harmadik pillérként ma már a közérdek, a közönség passzív befogadó szerepéből a megváltozott igények, lehetőségek folytán való átalakulása, aktív tartalom-előállító szerepének kiteljesedése, a közönség fogyasztóvá válása, annak tág

12 1999. évi LXXVI. törvény a szerzői jogról (Szjt.).

${ }^{13}$ Garamvölgyi Andrea fordítása. 
értelmében (nemcsak befogadó, hanem termelő tevékenység is).${ }^{14}$ Kicsit más oldalról közelítve, a szerzői jog örökös dilemmája, és sokszor kibékíthetetlennek tủnő ellentéte, ${ }^{15}$ hogy hogyan biztosítható az információhoz való minél szélesebb körű hozzáférés, a korlátozások minimalizálásával (innovation today), és ezzel egyidőben hogyan lehet a szerzők érdekeit minél teljesebb körü védelemben részesíteni, ezáltal a kreatív folyamatokat minél jobban ösztönözni (innovation tomorrow). ${ }^{16} \mathrm{Ez}$ az utilitarista megközelítés. A szellemi tulajdonjogok közül is a szerzői jog kiemelt jelentőséggel bír az innováció, és azon keresztül a gazdasági növekedés, fejlődés ösztönzése tekintetében, mégpedig azáltal, hogy a tudás közkinccsé válásának, terjesztésének, az ahhoz való hozzáférésnek a kereteit adja meg, így a klasszikus közgazdaságtanban a növekedés egyik fő tényezőjeként meghatározott emberi erőforrás minőségéhez, szakértelméhez járul hozzá. ${ }^{17}$

A jogi szabályozásnak tehát olyannak kell lennie, hogy ne gátolja, hanem inkább ösztönözze mind a szellemi termékek létrejöttét, mind azok felhasználását. Így például a szerzői jogászok közül egyesek akként vélekednek, hogy a fájlcsere büntethetőségével kapcsolatban nem abban kell állást foglalni, hogy erkölcsileg elítélendő-e a fájlcsere vagy sem, hanem ezen a kérdésen felülemelkedve egyrészt az információs társadalom alapkövetelményét, az információk szabad áramlásának elvét kellene előtérbe helyezni, másrészt a szerzők, kiadók, a könyv-, zene- és filmipar más képviselőinek érdekét is figyelembe kellene venni. Napjainkban a könyvkiadók, zenemükiadók stb. kénytelenek újabb és újabb alternatív üzleti modelleket felállítani, kreatív üzleti fogásokat alkalmazni, hogy életben maradjanak. Ez azt jelzi, hogy a szerzői jogi szabályozás jelenleg nem fenntartható, nincs meg a kívánt egyensúly. ${ }^{18}$ A fenntartható szerzői jogi szabályozás az érdekek egyensúlya vonatkozásában olyan (lenne), amely egyszerre képes biztosítani az akadálytalan hozzáférést és a szerzői jogok hatékony, magas szintü védelmét. ${ }^{19}$

A 20. században a kívánt, ugyanakkor törékeny egyensúly a felhasználási módok megsokszorozódása, a szerzői jogot megrendítő „exponenciális sokk”20 okán a felhasználók előnyére borult fel, így a szerzői jog feladata elsősorban az volt, hogy a szerzőknek, alkotóknak, múvészeknek oltalmat biztosítson a kalóz, illetve potyautas felhasználókkal szemben. ${ }^{21}$ A magyar szerzői jogi jogalkotást tekintve ez az új szerzői jogi törvény 1999-es megalkotásakor is látható volt, ugyanis a jogszabály preambulumában is kifejezetten utal a szerzői jog új kihívásaira, és azokra választ kíván adni. Kifejezetten szerepel benne, hogy a technikai fejlődés révén felmerült kihívásokra hosszú távú, maradandó megoldásokat adjon. ${ }^{22}$

${ }^{14}$ PogÁcsÁs Anett: Tartalomáramlás és hozzáférés a szerzői jog „fogyasztói korszakában.” In Medias Res, 2017/1, 146. [a továbbiakban PogÁcsás (2017a)]

15 Pogácsás (2017a): i. m., 146.

${ }^{16}$ VAN DEN BERGH, Roger: The Role and Social Justification of Copyright: a "Law and Economics" Approach. Intellectual Property Quarterly, 1998/1, 17-34.

${ }^{17}$ KESERŰ Barna Arnold: A szellemi tulajdon a fenntartható fejlődés szolgálatában I. A szellemitulajdon-jogok hatása a fejlődésre. Iparjogvédelmi és Szerzői Jogi Szemle, 2015/4, 7.

${ }^{18}$ LESSIG, Lawrence: Szabad kultúra. A kreativitás természete és jövője. Kiskapu, Budapest, 2005, 187-230.

${ }^{19}$ PogÁcsÁs (2017a): i. m., 167-168.

${ }^{20}$ PogÁcsÁs (2017a): i. m., 146.

${ }^{21}$ VAN DEN BERGH: i. m., 33-34.

${ }^{22}$ Az Szjt. javaslatának miniszteri indokolása. 
A szerzői jogban jellemző kizárólagos jogok nem jelentik egyúttal azt, hogy ezek korlátlanok, abszolút jogok is lennének. A szerzői jogi kizárólagos jogosultságok ugyanis időben és tartalmukban is korlátozottak. A korlátok azonban folyamatos revízióra szorulnak, a határokat minden korban újra és újra kell szabni. Így időről időre felmerül az igény a védelmi idő kérdésének vagy a szabad felhasználási módoknak az újraszabályozására. Mára a hangsúly eltolódott a többszörözési jogtól a terjesztés és a nyilvánossághoz közvetítés felhasználási formái irányába. ${ }^{23}$

Ez a szerepkör vagy törekvés a 21. században jelentős átalakuláson megy keresztül; főként, de nem kizárólag az online felhasználások terjedésének következménye olyan technikai megoldások általánossá válása, amelyek lehetővé teszik a szerzők számára az abszolút kontroll megvalósítását. Ezen túlzott kontrollal szemben szükséges a felhasználók érdekeinek is érvényt szerezni, elsősorban a kreativitás szempontjából, de az információk disszeminációja szempontjából is. A kreativitás kibontakozásához alapvető fontosságú, hogy az alkotások tulajdonjogát birtoklók ne tarthassák teljes kontroll alatt az alkotótevékenységet. Ez a gondolat visszajut oda, hogy a szellemi tulajdonjogok körében nem biztosítható a jogtulajdonosok számára ugyanolyan körü jogosultság, mint a dologi tulajdon esetében, mert ez visszaélésekre adna okot. ${ }^{24} \mathrm{~A}$ szellemi tulajdonjogok esetében ugyanis van egy vissza-visszatérő vitás kérdés, hogy tudni illik mennyiben hasonlítanak a dologi jogi tulajdonjoghoz. Mindkét tulajdonjog-típus negatív tartalmú, abszolút szerkezetủ ugyanis. ${ }^{25} \mathrm{Ez}$ az abszolút szerkezet azonban napjainkra kezd eltünni, amely tendencia kiváltói a szerzői jog korlátai vagy a szerzői vagyoni jogoknak az alapjogokkal szembeni háttérbe szorulása. ${ }^{26} \mathrm{~A}$ mủ hordozóját illető jelentős változás nyomán a dolgokra vonatkozó tulajdonjog-fogalom egyre kevésbé alkalmazható a szellemi alkotásokra, sokkal inkább a szellemi erőfeszítésen fennálló tulajdonjoggá alakult. ${ }^{27}$ Ez visszakapcsolható a mü feletti kontroll kérdésköréhez, amellyel kapcsolatban fontos látni, hogy az engedélyezési jog napjainkban jelentős átalakuláson megy keresztül. Ahogyan fentebb is említettem, a szerzői jog külső és belső korlátai folyamatosan változnak, ezzel újraértelmezve az engedélyezési jog és a hozzáférési jog (és ezzel együtt tulajdonképpen a szerzői jog) terjedelmét. ${ }^{28}$

Ha ugyanezt a kérdést földrajzi viszonylatba helyezzük, leegyszerüsítve tendenciaként az rajzolódik ki, hogy a szellemitulajdon-exportőr államok érdeke, hogy erős szellemi tulajdonjogok legyenek (saját szellemi termékeiket minél jobban tudják oltalmazni), a fejlődő országok illetve a szellemitulajdon-importőr államok álláspontja viszont éppen ellenkező (minél könnyebben hozzájussanak más államok szellemi termékeihez). Időnként megfogalmazódnak szélsőséges álláspontok a szerzői jog elvárt minőségével kapcsolatban: vagy a teljes engedélyhez kötöttség, vagy a teljes szabadság mellett érvelnek. Ezen szélsőségek megjelenése főként az angolszász

\footnotetext{
${ }^{23}$ PogÁcsás (2017a): i. m., 150.

${ }^{24}$ LESSIG: i. m., 99.

${ }^{25}$ FICSOR Mihály Zoltán: A szellemi tulajdon és a Ptk. Polgári Jogi Kodifikáció, 2001/2, 27.

${ }^{26}$ GYENGE Anikó: Alkotmányossági kérdések a szerzői jogban. Iparjogvédelmi és Szerzői Jogi Szemle, 2003/5, https://www.sztnh.gov.hu/hu/kiadv/ipsz/200310/01-gyenge.html (2020. 08. 24.).

27 JÜTTE, Bernd Justin: The Beginning of a (Happy?) Relationship: Copyright and Freedom of Expression in Europe. European Intellectual Property Review, 2016/1. - idézi: PogÁcsás (2017a): i. m., 151.

${ }^{28}$ PogÁcsÁs (2017a): i. m., 147-160.
} 
szerzői jogi rezsimekre jellemző, azon belül is az Amerikai Egyesült Államokban. A kontinentális jogrendszerekben mindig inkább valamilyen középutat, egyensúlyi helyzetet próbálnak elérni a szerzői jogi szakértők, jogalkotók. Jó példa erre az európai szerzői jogi jogharmonizációs folyamat, amely a történelmi léptékek szerint még napjainkban is új technikai vívmánynak számító Internetet és az ahhoz kapcsolódó digitális környezetet is növekvő mértékben szabályozás alá kívánja vonni. Az InfoSoc irányelv már nem képes lefedni a 21. század követelményeit, így a hoszszas jogalkotó folyamat eredményeképpen megszületett szerzői jogi irányelv kívánja a szabályozást komplexebbé, modernebbé és fenntarthatóbbá tenni. ${ }^{29}$

A kontinentális szerzői jogi rezsimekben kifejezetten a fenntarthatóságot szolgálja a szabad felhasználási módok szabályozása, mivel ez mind a szerzők, mind a felhasználók érdekeit szem előtt tartva szab szigorú kereteket a felhasználásnak, ugyanakkor a technika és a szerzői jog fejlődési tendenciáira a szabad felhasználási formák bővítésével reagál. A szabad felhasználási módok szabályozása azáltal képes betölteni szerepét, hogy egyrészt zárt kört alkot, tehát a kör tágulását ellensúlyozza, hogy csak a rögzített szabad felhasználási módok alkalmazhatók, másrészt pedig a felhasználás terjedelme is pontosan meghatározott, többek között egy háromlépcsős teszt szab korlátot a felhasználás határai értelmezésének. ${ }^{30}$ Napjainkra a háromlépcsős teszt értelmezése, alkalmazása valamelyest rugalmasabbá kezd válni nemzetközi szinten (2008-as Müncheni Nyilatkozat, ${ }^{31}$ a 2021-ben publikált International Instrument on Permitted Uses ${ }^{32}$ ). Ez veszélyes vizekre vezeti a szerzői jogot, és ténylegesen vitatott is ezen irány helyes volta. Kérdésként merül fel egyrészt, hogy a kívánt egyensúly nem tolódik-e el éppen ezen újabb interpretációk nyomán aránytalanul a szabad felhasználások, a hozzáférés érvényesülésének irányába. Másik kérdés pedig az lehet, hogy ezen iránymutatás-jellegű dokumentumoknak milyen hatása lehet a háromlépcsős teszt értelmezésének irányaira, a nemzetközi jogfejlődésre (lévén, hogy ezek nem nemzetközi szerződések). ${ }^{33}$

A szerzői jogi kivételek és korlátozások esetében fontos látni, hogy azok mindig csak célhoz kötötten jelenhetnek meg. Ez azt jelenti, hogy valamilyen közérdekủ célnak kell fennállnia, amelyhez kapcsolódóan a hozzáférés megkönnyítése indokolt: ilyen célok például az oktatás, a kutatás, a fogyatékos személyek vagy a könyvtári hozzáférés. ${ }^{34} \mathrm{~A}$ célhoz kötöttség elve régóta jelen van a szerzői jogi korlátozások és kivételek körében, de napjainkban talán minden korábbinál nagyobb jelentőséget nyer.

Ugyancsak a fenntarthatóság szem előtt tartásával az európai szerzői jogi jogharmonizáció törekszik a tartalomáramlás akadályainak lebontására, a határokon

\footnotetext{
${ }^{29}$ Az Európai Parlament és a Tanács (EU) 2019/790 irányelve (2019. április 17.) a digitális egységes piacon a szerzői és szomszédos jogokról, valamint a 96/9/EK és a 2001/29/EK irányelv módosításáról, HL L 130., 2019.5.17., 92-125. o.

30 GYENGE (2003): i. m.

${ }^{31}$ Declaration for a Balanced Interpretation of the Three-Step Test in Copyright Law. Max Planck Institut, Munich, 2008.

32 International Instrument on Permitted Uses in Copyright Law. Max Planck Institut, Munich, 2021.

${ }^{33}$ GYENGE Anikó: Szerzői jogi korlátozások és a szerzői jog emberi jogi háttere. HVG-ORAC, 2010, 88-89.

${ }^{34}$ PogÁcsás (2017a): i. m., 160.
} 
átnyúló hozzáférés és hordozhatóság biztosítására - teszi ezt ugyanakkor a szerzői jogot alapvetően jellemző territorialitás fenntartása mellett, a lehetőségekhez mérten. ${ }^{35}$

Ez egyébként nemcsak az európai jogharmonizáció törekvése, ugyanis már a szellemi tulajdon kereskedelmi vonatkozásairól szóló TRIPS-megállapodás (1994) preambuluma is a magas szintű védelem mellett fontos szempontként hangsúlyozta, hogy „a szellemi tulajdonjogok kikényszerítésének eszközei és az erre szolgáló eljárások ne váljanak a jogszerü kereskedelem akadályává." Ez azt jelenti, hogy mind az elégtelen, mind az eltúlzott mértékű védelem a jogszerủ kereskedelem torzulásához vagy akadályozásához vezethet. Előbbi azáltal, hogy teret enged a kalózkodásnak és a hamisításnak, utóbbi pedig azáltal, hogy a kívánt hatással ellentétes, kontraproduktív hatást ér el. ${ }^{36}$

A szerzői jogban az egyensúly létrejöttét és fenntartását jelentős mértékben befolyásolja a közkincs kérdéséhez való aktuális hozzáálás is. Míg hagyományosan a közkinccsel szembeni attitüd lényege a szellemi tulajdonjog hiánya, annak megszünése volt, a közkinccsé süllyedés folyamata (negatív megközelítés), napjainkban pozitív megközelítéssel, a szerző és a közérdek közötti egyensúly irányában hatva a közkincset a szellemi tulajdonjog dinamikus, közösségi dimenziójának tekintik, amikor egy alkotás közkinccsé emelkedik, nemesedik, hozzájárulva az emberiség közös tudásának gyarapodásához. ${ }^{37}$

A közkincs kérdésének ma már a korábbinál jóval nagyobb jelentőséget tulajdonítanak. A közkincsbe tartozó művek körének tág vagy éppen szűk volta a kultúrához, a tudáshoz való hozzáférés valamint ezzel szorosan összefüggésben a szerzői jogi kivételek és korlátozások minősége, határa a fenntarthatóság szempontjából rendkívül releváns. ${ }^{38}$ Egy mü közkincshez tartozásának több formája van - a védelmi idő lejárta, a védelemről való lemondás, a szerzői művel szemben támasztott pozitív követelmények (eléri-e azt a küszöböt, amelytől szerzői műnek minősül), védelemből kizárt múvek, ötletek.

Napjaink törekvései nemzetközi szinten egyértelműen a közkincs szélesítésére mutatnak, a hozzáférési jog minél szélesebb körű biztosítása érdekében. ${ }^{39} A$ World Intellectual Property Organization (WIPO) égisze alatt 2007-ben elfogadott, negyvenöt ajánlást tartalmazó Development Agenda két ajánlása kifejezetten a közkincscsel foglalkozik. ${ }^{40} \mathrm{~A} 16$. ajánlás a közkincs szerepének fenntartásáról és hatásainak elemzéséröl szól, a 20. ajánlás pedig a WIPO számára feladatként jelöli meg, hogy segítse az országokat a közkincs saját jogrendszerükben történő körülhatárolásában.

Korábban már kiemeltem, hogy a kulturális fenntarthatóság - és ennélfogva a szerzői jogi fenntarthatóság - kapcsán rendkívül fontos a kulturális sokszínü-

\footnotetext{
${ }^{35}$ PogÁcsÁs (2017a): i. m., 167.

${ }^{36}$ GeRVAIS, Daniel: The TRIPS Agreement: Drafting History and Analysis. Sweet\&Maxwell, 2021, 3-10.

37 KESERŰ (2015): i. m., 16-17.

${ }^{38}$ KESERŰ Barna Arnold: A fenntartható fejlődés hatása a szellemitulajdon-védelem rendszerére. Dialóg Campus, 2019, 142-152.

39 KESERÜ (2019): i. m., 152.

40 The 45 Adopted Recommendations under the WIPO Development Agenda, 2007. https://www.wipo.int/export/sites/www/ip-development/en/agenda/recommendations.pdf (2021. 04. 28.).
} 
ség megőrzése. Nemzetközi szinten, a szellemitulajdon-védelem új területei között szerepel a hagyományos kulturális kifejeződések védelme, amely területet tágabb környezetben a szellemi kulturális örökség szellemitulajdon-védelmi aspektusaként tartanak számon. A kulturális kifejeződések körébe tartozó értékek, alkotások, szokások képezik a kulturális sokszínűséget. A kulturális sokszínűség pedig jelentős szerepet tölt be egy közösség adaptációs képességében, megóvja a közösséget az uniformizálódástól. ${ }^{41}$ Ebben a körben visszakapcsolódunk a közkincs kérdéséhez. A közkincs ugyanis alkalmas a kulturális sokszínüség, a tudás, a gondolatok sokféleségének hozzáférhetővé tételére. A hozzáférés és a kulturális sokszínűség kétségtelenül egymással párhuzamosan alakuló területek.

\subsection{A filozófiai-alapjogi háttér változása}

A szerzői jognak napjainkban már nem biztosít kellő megalapozást az a filozófiai háttér, amelynek alapjain létrejött. Az iparosodási, polgárosodási folyamatok és az ezek jogfilozófiai megalapozását jelentő természetjog képezte a modern szerzői jog alapját. Ezt azonban a 20., de még inkább a 21. század kihívásai meghaladták; ma már új szilárd hátteret és fejlődési ugrópontot jelentenek az emberi jogok, illetve az alkotmányos alapjogok. A szerzői jog egyes részjogosultságait is az alkotmányos alapjogokból vezetik le. Ez a tendencia visszavezethető a szerzői jogban érvényes azon törekvésre, hogy az új egyensúly felállásához többé nem a szerzőt részesíti előnyben a szerzői jog, hanem egyre erősödő pozíciót foglalnak el a felhasználók is a jogaik érvényesítése kapcsán. Ez pedig hatással van a szerzői vagyoni és személyhez fúződő jogok fejlődésére is. Ezt a 3.3. alfejezetben tárgyalom részletesebben.

Korábban a szellemi tulajdont a dologi jogi tulajdonnal párhuzamosan kezelhetönek, azzal egyenértékủnek tartották. Mára azonban már határozottan kirajzolódtak azok a pontok, amelyek elhatárolják a két fogalmat. A nemzetközi, az európai uniós és a magyar jogalkalmazás is csak lassan kezd azonban nyitni a tulajdonhoz való jog felől más alapvető emberi jogok alkalmazásának irányába a szerzői jogi vonatkozású ügyekben.

Az Emberi Jogok Egyetemes Nyilatkozatának (EJENY, 1948) 27. cikke alapján „1. Minden személynek joga van a közösség kulturális életében való szabad részvételhez, a müvészetek élvezéséhez, valamint a tudomány haladásában és az abból származó jótéteményekben való részvételhez." Ezen általánosan biztosított jogokhoz képest a második bekezdésben jelenik meg a szerzői jog: „2. Mindenkinek joga van minden általa alkotott tudományos, irodalmi és müvészeti termékkel kapcsolatos erkölcsi és anyagi érdekeinek védelméhez." Egyesek a fenti szabadságjogok korlátozásaként, ${ }^{42}$ míg mások éppen ezek gyakorlásának garanciájaként értelmezik a szerzői jogot, és a fenti kulturális jogokat tekintik a szerzői jog korlátozásának. ${ }^{43}$

${ }^{41}$ KeSERÜ (2019): i. m., 240-241.

42 KESERŰ (2019): i. m., 135.

${ }^{43}$ GYENGE (2010): i. m., 23. 
Ezzel a dokumentummal emelkedett a szerzői jog az emberi jogok körébe, és itt már látható a tulajdonhoz való jogtól történő elválasztása, hiszen nem ahhoz, hanem a kulturális jogokhoz kapcsolták a szerzői jogot. Ehhez képest az Emberi Jogok Európai Bírósága (EJEB) gyakorlatára csak az utóbbi 15-20 évben jellemző, hogy a szerzői jogi vonatkozású ügyek elbírálása során a korábban kizárólagosan alkalmazott tulajdonhoz való jogon ${ }^{44}$ (Emberi Jogok Európai Egyezménye, EJEE, 1950, 1. kiegészítő jegyzőkönyv 1. cikk) túl is tekint, és más alapjogokat is segítségül hív - az EJEE 10. cikkében foglalt véleménynyilvánításhoz való (és az ebből levezethető, információhoz jutáshoz való) jogot. ${ }^{45}$ Ugyanakkor meg kell említeni, hogy az EJEE nem tartalmaz semmilyen utalást a szerzői jogra.

A Gazdasági, Szociális és Kulturális Jogok Nemzetközi Egyezségokmányának (GSZKJNE, 1966) 15. cikke lényegében megismétli az EJENY szövegét, és szintén a kulturális jogok között helyezi el a szerzői jogot.

Az EJENY és a GSZKJNE által kijelölt vonalat megtörte a Szellemi Tulajdon Világszervezete létrehozásáról szóló egyezmény (1967), amely egyrészt sem ezen korábbi dokumentumokra, sem a szerzői jognak az emberi jogokkal való kapcsolatára nem utalt, ${ }^{46}$ csak célként tűzte a szerződő felek számára, hogy az egész világon erősítsék a szellemi tulajdon oltalmát. A 2008-ban létrejött UNESCO-Egyezmény a kulturális sokszínúségről visszahelyezte a szellemi alkotásokon fennálló jogokat az emberi jogi, kulturális jogi alapokra, kapcsolatot teremtve az EJENY-nyel és egyéb nemzetközi dokumentumokkal, ugyanakkor csak igen általánosan szólt a szellemi tulajdonjogokkal való viszonyáról. ${ }^{47}$

A nemzetközi emberi jogi egyezmények és a nemzetközi szerzői jogi tárgyú egyezmények kapcsolatát illetően látnunk kell, hogy az csak közvetett lehet, hiszen a szerzői jogi egyezmények nem az emberi jogi egyezmények mentén jöttek létre, azonban az emberi jogi egyezmények lassan elkezdtek tekintettel lenni a szerzői jogi egyezményekre, és azoknak megfelelően elismerni a szerzői jogot. ${ }^{48}$

Az európai közösségi jog fejlődése nem áll párhuzamban a fenti nemzetközi fejleményekkel. Az Alapjogi Charta egyrészt elismeri a múvészeti és tudományos szabadságot (13. cikk), azonban nem ezen kulturális jogok körében, hanem a 17. cikkben, a dologi tulajdonjoggal foglalkozó (1) bekezdése mellett a (2) bekezdésben mondja ki a szellemi tulajdon védelmét. Ugyanakkor nem jelöli meg a védelem tartalmát és korlátait. Ennek ellenére mind a szellemi tulajdon helyének kijelölése, mind a kulturális alapjogok biztosítása miatt a Charta fontos uniós dokumentumnak tekinthető. ${ }^{49} \mathrm{~A}$ Lisszaboni Szerződés, amely a Chartát kötelező erőre emelte és az alapszerződésekkel azonos szintű dokumentumként ismerte el, emellett azt is tartalmazta, hogy az EU csatlakozik az EJEE-hez, tehát az EJEE által biztosított jogokat

\footnotetext{
${ }^{44}$ Melnychuk v. Ukraine ügyben, 28743/03. sz., 2005. 07.05. napján hozott ítélet.

${ }^{45}$ Wissenschafts-Trend Zeitschriften - Verlagsgesellschaft mbH (no.3) v Austria ügyben, 66298/01. és 15653/02. sz., 2005. 12. 13. napján hozott ítélet; Krone Verlag GmbH \& Co. KG v Austria ügyben, 34314/96. sz., 2008. 11. 14. napján hozott ítélet.

${ }^{46}$ GYENGe (2010): i. m., 26.

47 GYENGE (2010): i. m., 29-30.

48 GYENGE (2010): i. m., 94.

${ }^{49}$ GYENGE (2010): i. m., 34-35.
} 
elvileg az EU-ban is biztosítani kell. Ennek érdekében az EU Bírósága és az EJEB konzultációt folytat egymással. A szerzői jog elhelyezkedése az Alapjogi Charta rendszerében (a dologi tulajdon körében) nehezen összeegyeztethető az EJEB fent részletezett gyakorlatával (a véleménynyilvánítás jogának alkalmazása). ${ }^{50}$

Az EU-ban zajló szerzői jogi reform kezdetekor, 2015-ben kiemelten fogalmazta meg az EB, hogy a fogyasztók magánélethez és személyes adatok védelméhez való jogát a piaci innováció ösztönzése mellett a digitális egységes piacon biztosítani kell. A stratégia főbb célkitűzései a szerzői jog fenntarthatóvá tételének megvalósítására irányulnak: az internetes termékek és szolgáltatások elérhetőbbé tétele az európai fogyasztók és vállalkozók számára, a digitális hálózatok és szolgáltatások fellendülését elősegítő infrastrukturális és jogi feltételek megteremtése, az európai digitális gazdaság növekedési potenciáljának maximalizálása, az internetirányítás fenntarthatóságának kialakításával. Kifejezett cél, hogy a digitális gazdaság hozzájáruljon a társadalom befogadóbbá válásához. ${ }^{51}$

Miközben a szerzői jogi reform célul tűzi ki például a tudáshoz, oktatáshoz való hozzáférés határokon átnyúló egységes biztosítását a digitális egységes piacon a vonatkozó kivételek és korlátozások egységesítésével, a megvalósítás formája, az irányelvi keret nem alkalmas ezen cél maradéktalan elérésére, mert a tagállamok a meglévő rendszereikhez igazítják a közös szabályokat. Ez a probléma már az InfoSoc-irányelv kapcsán is felmerült, azonban úgy tünik, most sem sikerül orvosolni. ${ }^{52}$

A 2019-ben elfogadott szerzői jogi irányelv nagy hangsúlyt fektet a véleménynyilvánítás szabadságának érvényesülésére, elsősorban a digitális és online környezetben, például a mémek és a paródia szabad felhasználási formaként történő elismerése ${ }^{53}$ által. Ez a felhasználók oldalát erősíti. Ugyancsak a felhasználók jogainak, illetve a közérdeknek az érvényesítését segíti az, hogy a szerzők mellett immár a kiadók méltányos díjazáshoz való jogát is elismeri - habár ebben a kérdésben a tagállamok szabadon rendelkezhetnek. ${ }^{54}$ Mind a szerzők, mind a felhasználók számára hatékony jogérvényesítési mechanizmusok bevezetését irányozza elő a kifogások kezelése terén.

A nemzetközi törekvések ellenére a magyar szerzői jogi törvény jelenlegi formájában kifejezetten még nem kapcsolja a szerzői jogot az alkotmányos alapokhoz, csak a törvényjavaslat indokolásában találunk erre vonatkozó utalást. „A szerzői vagyoni jogok is részesednek abból az alkotmányos védelemből, amely a 17/1992. (III. 30.) $A B$ határozat értelmében az Alkotmánynak a tulajdonjogot oltalmazó rendelkezéseiből következik. [...] Másfelöl alaposnak látszik az a feltevés, hogy az Alkotmány 54. §-ának (1) bekezdése alapján a szerző személyhez füződő jogainak védelme az általános személyiségi jognak is részét képezi, az emberi méltóság védelmének

50 GYENGE (2010): i. m., 36.

51 A Bizottság Közleménye az Európai Parlamentnek, a Tanácsnak, az Európai Gazdasági és Szociális Bizottságnak és a Régiók Bizottságának. Európai digitális egységes piaci stratégia, 2015, COM(2015) 192 final.

52 KASKOVITS Melinda: Szerzői jog a digitális egységes piacon. Infokommunikáció és Jog, 2017. évi különszám, 25-32.

53 2019/790/EU irányelv 17. cikk (7) bekezdés b) pont.

54 2019/790/EU irányelv 16. cikk. 
sajátos vonzataként jelenik meg. ${ }^{355} \mathrm{Az}$ Szjt. már idézett preambuluma utal ugyan további alapjogokra, de nem nevezi meg konkrétan azokat, illetve nem teremt egy átfogó alapjogi bázist, amely az egyensúlyra való törekvésben segítségünkre lehetne. Érintőlegesen sem hivatkozik azokra a további, kézenfekvőnek tủnő alapjogokra, amelyek megfelelő bázist nyújtanának a kívánt érdekegyensúly, illetve az alkotás ösztönzésének előmozdításához, mint például a művészeti és tudományos szabadság vagy a kulturális jogok. ${ }^{56}$ Így tehát elsősorban a jogirodalom és a jogalkalmazás (az Alkotmánybíróság) teremti meg a kapcsolódási pontokat az alkotmányos alapjogok és a szerzői jog között. A Szjt. 1999-es hatályba lépése óta nem nyúlt a jogalkotó a preambulumhoz, ezzel együtt rendezetlenül hagyta a szerzői jog és az alapjogok viszonyát. A nemzetközi tendenciák és az európai szerzői jogi irányelv által mutatott út alapján azonban nyilvánvalóan a magyar jogalkotónak is lépéseket kell tennie egy olyan szerzői jog felé, amely az alapjogokat az eddiginél kiterjedtebb mértékben respektálja, és nemcsak általános utalások szintjén, hanem konkrétan megfogalmazott rendelkezések által.

Fentiek alapján azt mondhatjuk, hogy a szerzői jog akkor lehet fenntartható, ha a korábbinál szélesebb körben elismerik a kultúrához kapcsolódó emberi jogokat mint a szerzői jog alapjogi hátterét, és ezen alapjogoknak a többnyire csak a joggyakorlatban formálódó elismerése határozottan megjelenik a nemzetközi, európai uniós és a magyar jogforrásokban is.

\subsection{Vagyoni jogok és személyhez füződő jogok}

A szerzői jog mai formája, rendszere az iparosodással párhuzamosan alakult ki - ahogyan a középkorban elindult technikai fejlödés (könyvnyomtatás) párosult többféle társadalmi, politikai és gazdasági tényezővel, a múvészet, a könyvkiadás is kezdett iparággá fejlődni, amely magával hozta a befektetési szemléletet. Az új környezetben szükségképpen megjelentek bizonyos privilégiumok és később jogi normák is. A személyhez füződő jogok koncepciói a 18. században kerültek a szerzői jogi gondolkodásba, Kant, Fichte és Hegel munkássága nyomán. Jogi kereteket azonban először 1928-ban kaptak, az 1886-os Berni Uniós Egyezmény római felülvizsgálata alkalmával, amikor a 6. cikk meghatározott egy minimum standardot. A személyhez fűződő jogok kialakulása idején a szerzők oldalán a vagyoni motiváció ekkor még kevéssé volt jellemző. Lassan azonban a vagyoni jogok is utat törtek maguknak, olyannyira, hogy a polgárosodás idejére a személyhez füződő jogok és a vagyoni jogok egymáshoz értek. A 20. század második felétől azonban újra távolodtak egymástól, a vagyoni jogokra nagyobb hangsúly került, ahogy a befektetési szemlélet a művészet és a tudomány különböző területeit is uralni kezdte. ${ }^{57}$

\footnotetext{
${ }^{55}$ Miniszteri indokolás az 1999. évi LXXVI. törvény javaslatához.

${ }^{56}$ GYENGE (2003): i. m.

57 PoGÁcsÁs Anett: Különbözőség az egységben. A szerzői jogi szabályozás differenciálódásának hatása a jogterület szerepére és hatékonyságára. Pázmány Press, Budapest, 2017, 21-32. (https://doi.org/10.15774/ PPKE.JAK.2017.006) [a továbbiakban PogÁcsÁs (2017b)]
} 
A nemzetközi szerzői jogi jogalkotásban a legtöbb platformon mellőzték a személyhez fűződő jogokat, például a TRIPS-Egyezmény kifejezetten elhatárolódik ezen jogoktól. ${ }^{58}$

A szerzői vagyoni és személyhez füződő jogok állandóan változó viszonya napjainkban is a társadalmi-gazdasági folyamatokat képezi le, de ahogyan az előző fejezetben is láttuk, a szerzői jog alapjogi hátterének változása is kellő magyarázatot szolgáltat a szerzői jogok e két fő csoportja dinamizmusának megértéséhez.

Az európai szerzői jogi jogharmonizáció nagyjából 40 éves története során időről időre felmerült a szerzői vagyoni és személyhez fủződő jogok fejlődési irányának problémaköre, de az Európai Unió következetesen távol tartja magát a személyhez füződő jogok kérdésében való határozott álláspont kialakításától. ${ }^{59}$ Így történt ez az 1988-as Zöld könyv esetében, amelyben a személyhez füződő jogok kérdésének megjelenése csak problémafelvetésként értékelhető. Az InfoSoc-irányelv esetében is hasonlóképpen történt, ez alapján a tagállamok saját joga a kérdésben dönteni, illetve a hatályos nemzetközi egyezmények szerint gyakorolhatók ezek a jogok. 2013-ban a Bizottság széleskörű konzultációt folytatott, de a személyhez füződő jogok ekkor is csak érintőlegesen kerültek tárgyalásra. A 2015-ben megjelent közlemény ${ }^{60}$ ismét elvetette a kérdést.

A személyhez fúződő jogok mellőzésének okaként igen szerteágazó indokokat neveznek meg, ${ }^{61}$ hagyományosan arra hivatkoznak legtöbbször, hogy a common law és civil law jogrendszerekben eltérő a személyhez füződő jogok alapja; míg előbbiben az utilitarista koncepció domináns, amely a vagyoni jogok jelentőségét erősíti, utóbbi államokban a természetjogi megközelítést fogadják el, amely viszont erős individuális jogokat hoz magával. A 21. században azonban az lenne megfeleIő, ha a kétféle szerzői jogi filozófia erős elemeit ötvözve sikerülne egy koncepciót alkotni. További érv, hogy az egyes érdekcsoportok érdekellentéteit olyannyira kibékíthetetlennek minősítik, hogy nem képzelhető el kompromisszumos megoldás. Harmadik ellenérv a személyhez füződő jogok szabályozásával szemben a felhatalmazás hiánya. Erre előszeretettel hivatkozik az Európai Bizottság, azonban az évtizedek során, az IP-jog egyre részletesebb harmonizációs folyamata révén az EU már korábban is határozott álláspontot foglalt el bizonyos érzékeny kérdésekben. A személyhez füződő jogok kérdéskörét is egyébként ilyen „egyéb, megfontolást igénylő érzékeny" területté minősítette. Miközben egyes konkrét ügyekben az EU Bírósága markánsan állást foglal, az EU jogalkotó szervei következetesen elhatárolódnak a problémától. Mindhárom érv, amely a személyhez füződő jogok harmonizációja ellen szól, egyszerủen megcáfolható, elég csak arra gondolni, hogy a vagyoni jogok terén ugyanezen dilemmák merülhettek és merülnek fel ma is, azok azonban korábban és napjainkban is részét képezik a harmonizációs folyamatnak. Ha az európai szerzői jogi harmonizációs folyamatot tekintjük, elmondható, hogy egy igen meghatározó,

\footnotetext{
58 JANSSENS, Marie-Christine: Invitation for a 'Europeanification' of Moral Rights. In: Torremans, Paul (szerk.): Research Handbook on Copyright Law. E. Elgar Publishing, Cheltenham, Northampton, 2017, 202.

59 JANSSENS: i. m., 202-203.

${ }^{60}$ A Bizottság közleménye az Európai Parlamentnek, a Tanácsnak, az Európai Gazdasági és Szociális Bizottságnak és a Régiók Bizottságának. A korszerü, európaibb szerzői jogi keret felé, 2015, COM (2015) 626 final.

61 JANSSENS: i. m., 204-232.
} 
hosszú szakaszban nem egy átfogó, egységes szerzői jogi szabályozás irányába haladt a folyamat, hanem egy-egy speciális területen (szoftverek, adatbázisok) vagy egyes speciális felhasználási formákról (bérlet, követő jog) születtek jogszabályok, irányelvek. Ez a lépcsőzetes megközelítés ${ }^{62}$ azonban nem bizonyul olyannak, mint ami a fenntarthatóságot szolgálná. Természetesen a személyhez füződő jogok harmonizációja nem képzelhető el ugyanúgy, mint a vagyoni jogok esetében, ezen jogok más-más kulturális, társadalmi és történelmi beágyazottságára tekintettel. A személyhez füződő jogok erősítése, szerepük hangsúlyozása azonban fontos lenne nemzetközi és európai uniós szinten is.

A személyhez füződő jogokhoz való visszatalálás alapvető fontosságú lenne, erre egyre többen felhívják a figyelmet, és konkrét törekvések is megfogalmazódtak ez irányban. A személyhez füződő jogoknak a mai digitális környezethez és társadalmi prioritásokhoz való alkalmazása nélkül a szerzői jog nem tud megújulni, a modern elvárásoknak megfelelni. Újra kell definiálni a szerző, a művészi alkotómunka, a müalkotás fogalmait. A személyhez füződő jogok jelentősége az új digitális vívmányok következtében folyamatosan nő. Ráadásul a csak a vagyoni jogok harmonizációját célzó hozzáállás figyelmen kívül hagyja a felhasználások valódi folyamatát. A vagyoni jogok terén a kivételek, illetve korlátozások nem szabályozhatók elkülönítetten, csak a személyhez füződő jogok szellemiségével egységben - ezt a belső piac megfelelő működése teszi szükségessé. ${ }^{63}$ A 2015-ben kiadott Európai Bizottsági közlemény már arról tanúskodik, hogy érzékelni kezdték a terület egységes megközelítésének szükségességét, amely a szerzői jog két fő területének egységesítésén túlmenően egy egységes európai szerzői jogi kódex megalkotásának igényét is felvetette. ${ }^{64} \mathrm{Az}$ egységes szerzői jogi kódex több okból nem valósult meg máig sem. Jelentős akadályt képez az EUMSz 345. cikke, amely a nemzeti tulajdonjogi szabályozások függetlenségét rögzíti, és a szerzői jogot mindenhol alapvetően a tulajdonjog körébe tartozó speciális területként tartják számon. ${ }^{65}$ Másik említendő gátja az egységesítésnek a szerzői jog alapvető territoriális jellege, ami azt jelenti, hogy az EU tagállamaiban nincs egységes szerzői jogi jogcím, hanem a tagállamok számának megfelelő számú különböző jogcím létezik, így egy adott mű felhasználásához külön engedélyeket kell szerezni a tagállamokban. Ez utóbbi problémát a 2019-ben elfogadott új irányelv jelentősen csökkenti, a határon átnyúló felhasználások, engedélyezések előmozdításával. Ezek a törekvések egyúttal áthidaló megoldást kínálnak a territorialitás által jelentett problémákra. A territorialitás egyébként a szerzői jogot alapvetően jellemző, de rendkívül vitatott jelenség. Gyakran felmerülő kérdés, hogy lehetséges-e a területiség megtartásával, áthidaló megoldásokkal kezelni az ebből fakadó problémákat, vagy a territorialitás (vagy inkább az abból eredő problémák) lebontása lenne-e a járható út. Napjainkra - talán a fenntarthatóság jegyében

\footnotetext{
62 TóтH Andrea Katalin: Az európai szerzői jogi harmonizáció és a territorialitás kérdése. Iparjogvédelmi és Szerzöi Jogi Szemle, 2016/4, 10.

63 JANSSENS: i. m., 211-213.

64 JANSSENS: i. m., 220.

65 TATTAY Levente: Versenyképesség és szellemi alkotások az Európai Unióban. Budapest, Wolters Kluwer, 2016, 249.
} 
is - az előbbi attitűd jellemző szélesebb körben, ${ }^{66}$ azonban a kétféle megközelítést ötvöző elképzelések is megtalálhatók. ${ }^{67}$

A fentebb vázolt, a harmonizáció irányában ható minden igény és törekvés, így a territorialitás által felvetett problémák eliminálása is a szerzői jog fenntarthatóságát segítené, mégpedig azzal, hogy az áruk, a szolgáltatások, a munkaerő és a tőke szabad áramlását, így a szerzői jog versenyt korlátozó hatását enyhíti, ezen kívül pedig közelebb hozná egymáshoz a kontinentális és a common law-alapú szerzői jogi rezsimeket. Ugyanakkor az irányelv, az európai szerzői jogi reform sem vitte előrébb a személyhez fűződő jogok ügyét.

Az európai vezető akadémikusok közreműködésével 2010-ben indult Wittemprojekt azzal a céllal jött létre, hogy kidolgozzanak egy egységes európai szerzői jogi kódexet. Kiindulásként fel akarták hívni a figyelmet az európai szerzői jogi jogalkotást jellemző transzparencia-hiányra és inkonzisztenciára. ${ }^{68} \mathrm{~A}$ létrehozni kívánt kódex ugyanakkor nem lett volna teljesen komplex, ugyanis már a tervezetből is kimaradt néhány igen fontos terület, mint a szomszédos jogok, a követő jog, az adatbázisok, a szerzői jogi jogsértés jogkövetkezményei, a szerzői jogi szerződések joga stb. ${ }^{69}$ A projekt több ok közrehatása miatt elbukott: egyrészt az EUMSz 118. cikke nem ad ilyen irányú felhatalmazást az EU-nak, másrészt a szerzői jogi jogvédelem alakszerütlen volta miatt nehezen lett volna elképzelhető és a valóságban egymással párhuzamosan müködtethető nemzeti és uniós rendszer, harmadrészt több EUtagállam elutasító volt a tervezettel kapcsolatban. ${ }^{70}$

Az EU-ban tehát a szerzői jogi jogharmonizáció mindezidáig csak részeredményeket tudott felmutatni. Ki kell emelnünk azonban az Európai Unió Bíróságának szerepét a joghézagok betöltésében, a különböző területeken (például a szerzői jogi kivételek vagy a szerzői jogi védelem anyagi feltételei körében) történő egységes értelmezés kialakításában, a kiegyensúlyozott szerzői jogi rendszer müködéséhez szükséges rugalmasság biztosításában, amely szerepe olyannyira jelentős, hogy egyfajta jogharmonizációnak (court-made harmonisation) tekinthető. ${ }^{71}$

A szerzői vagyoni jogok másik fenntarthatósági vonatkozása a fenntartható jogdijjak kérdése. Az érdekek egyensúlya körében tisztáztam, hogy a szerzői jog terén új egyensúly kialakítására kell törekedni, amely minden szereplő számára kielégítő jogokat biztosít. A vagyoni jogok, és az azokat megtestesítő jogdíjak kapcsán is az a törekvés fogalmazódik meg, hogy az alkotók méltányos díjazáshoz jussanak, mert az kellő ösztönzést nyújt az alkotómunka folytatásához. A méltányos díjazáshoz való

\footnotetext{
66 PogÁcsÁs (2017b): i. m., 243-244, 258.

67 STROWEL, Alain: Towards a European Copyright Law: Four Issues to Consider. In: Stamatoudi, Irini-Torremans, Paul: EU Copyright Law - A Commentary. Elgar Commentaries, 2014, 21.04., 21.07-21.21. Strowel amellett érvel, hogy a kulturális sokszínüség vagy a nyelvi sokféleség által indokolt, a territorialitással összefüggő szerzői jogi korlátozások fenntartása szükséges, az egyéb, ugyancsak a territorialitásból eredő korlátozásokat azonban csökkenteni vagy egyenesen eltörölni kellene.

${ }^{68}$ Hugenholtz, P. Bernt: The Wittem Group's European Copyright Code. In: Tatiana-Eleni Synodinou (szerk.): Codification of European Copyright Law: Challenges and Perspectives. Wolters Kluwer, 2012, 339-354.

69 То́тн: і. m., 15.

70 TATTAY (2016): i. m., 249.

71 STROWEL: i. m., 21.02.
} 
jogra való törekvést az európai szerzői jogi reform is magáévá tette. A 2019/790/EU irányelvnek a szerzői jogok szempontjából jól müködő piac megteremtését célzó intézkedései körében kiemelt helyet kap a méltányos díjazáshoz való jog, amely egyrészt a kiadók számára (16. cikk), másrészt a szerzők és előadómúvészek felhasználási szerződéseiben (18-20. cikkek) garantálja a megfelelő és arányos díjazáshoz való jogot, átláthatósági kötelezettséggel megerősítve.

Az Artisjus az európai szerzői jogi reformot megelőzve, már 2011-ben megfogalmazta küldetésnyilatkozatában ${ }^{72}$ a magyar kultúra, a környezet és a fenntartható zeneipar iránti elkötelezettségét - a környezeti fenntarthatóságot előtérbe helyező Jogkezelés Zölden nevü programja mellett. Az Artisjus felfogásában a fenntartható zeneipar azt jelenti, hogy a kulturális piac és a jogdíjbevételek kiszámíthatók legyenek, a szerzők méltányos részesedést kapjanak a jogdíjakból, egyszerü és hatékony legyen a jogkezelés. A felhasználási feltételek és jogdíjak szabása kapcsán azt a célkitűzést tartja szem előtt, hogy eközben az iparág működése ne lehetetlenüljön el, ez az egyesület tevékenységében egyre nagyobb szerepet kap. A fenntarthatósági gondolattal társulva a közös jogkezelés területén egyre világosabban kirajzolódik mind külföldön, mind Magyarországon, hogy a közös jogkezelő szervezetek egyre kevésbé hatósági, hanem inkább szolgáltató tevékenységet vízionálnak.

A jogalkotás még csak gyerekcipőben jár a fenntartható szerzői jog és fenntartható jogdíjak megteremtése területén, de ahogyan fentebb látható, a jogalkotási folyamatokat sokszor megelőzve egy-egy kulturális, művészeti piaci szereplő vagy szervezet élen járhat a haladó gondolatok megfogalmazásában. ${ }^{73}$

\subsection{A szerzői jog versenyképessége}

A szerzői jog a versenyképességhez a szerzői jog kizárólagos gyakorlásán és a szerzői mű felhasználásán keresztül kapcsolódik. A mű csak a piacon kap valódi értéket, ott tud érvényesülni, szélesebb körben ismertté válni. A mű valójában termék, amelyre a gazdasági törvényszerüségek mindenképpen hatással vannak, még ha rendhagyó termékről van is szó, és ennek megfelelően a gazdasági folyamatok is rendhagyó módon tudnak hatni rá. ${ }^{74}$ Így a szerzői jog versenyképességét meghatározza, hogy a vagyoni jogok mennyire erősek a vizsgált földrajzi viszonylatban. A szerzői jogi versenyelmélet Elster nevéhez füződik. Az elmélet a szerzői jogok eredetét a vállalkozói érdekviszonyban határozza meg. Ez, illetve a verseny indokolja a szerzői jogok létét. Ez a koncepció teljes mértékben mellőzi a szerzői személyhez füződő jogokat, emiatt sok bírálat is érte. Hazánkban Boytha György fogalmazta meg Elsterre/ szemben, hogy éppen a szerzői személyhez fűződő jogok léte az, ami

\footnotetext{
72 https://www.artisjus.hu/egyesulet/kuldetes/

${ }^{73}$ Így tett például a dél-afrikai Aspire Aukciósház is, amely törvényi szabályozás hiányában, jelentős műpiaci szereplöként kezdeményezte a követő jogi jogdíj bevezetését az aukciós eladások kapcsán, hogy ezzel hozzájáruljon a múvészeti piac fenntartható müködéséhez. https://artthrob.co.za/2017/04/25/resale-rightsand-sustainability-in-conversation-with-aspire-auctions/ (2020. 11. 25.).

${ }^{74}$ GRAD-GYENGE Anikó-SARKAdy Ildikó: Közös jogkezelés az audiovizuális médiában. NMHH Médiatudományi Intézet, Budapest, 2014. https://nmhh.hu/dokumentum/191936/mk10_web.pdf; 51. (2020. 11. 25.).
} 
a versenyt csökkenti vagy meg is szünteti. Boytha emellett azzal sem ért egyet, hogy a verseny célzata tenné a szerzői műveken fennálló jogokat vagyoni jogokká. ${ }^{75}$

A fenntarthatóságra vonatkozó nemzetközi tendenciákból és az ezek keretét adó dokumentumokból egyértelműen kirajzolódik a két fogalom viszonya: a versenyképesség csak a fenntarthatóság keretein belül értelmezhető. ${ }^{76}$ Ennek ellenére napjainkban az látszik, hogy sokszor ellentétes értékek és érdekek mentén töltődik meg tartalommal a két fogalom. A versenyképesség szempontjai gyakran kerülnek a fenntarthatósággal összeegyeztethetetlennek tűnő helyzetbe. Mintha a versenyképesség elsősorban rövid távú versenyképességet jelentene, szemben a fenntarthatóságnak a jövő generációira tekintettel megfogalmazott szempontjaival. Különösen érzékelhető ez a tendencia az Európai Unióban, ahol a növekedést priorizálják, és bár ennek során tekintettel vannak a fenntarthatóság szempontjaira, a kétféle értékrendszer konfliktusából gyakran a növekedés és a versenyképesség (rövid távú) szempontjai kerülnek ki győztesen.

A szakirodalom nem egységes abban, hogy a versenyképesség pontosan mit is jelent, milyen dimenzióban értelmezendő fogalom. Beszélnek területi alapon megkülönböztetett versenyképességről és termékek, valamint vállalatok versenyképességéröl. Ezek mind különböző mozgatórugók alapján müködnek, más mérőszámokkal, más körülmények között. ${ }^{77}$

A szerzői jog vonatkozásában beszélhetünk egyrészt a fenntarthatóság gazdasági vetületéröl, amelynek tekintetében a folyamatos növekedés szempontjai érvényesülnek, a nemzetközi törekvések is erre mutatnak. Ezt tekinthetjük rövid távú versenyképességnek, vagy arra való törekvésnek. A növekedési tendenciák azonban ellentmondásba kerülnek a fenntarthatóság szempontjaival, éppen a rövid távú perspektívájuk okán. Így valójában szinte elérhetetlen cél a gazdasági fenntarthatóság. A szerzői jogra vetítve, napjainkban sokszor felmerül, hogy akár a nemzetközi, akár az európai uniós szabályozási törekvések a fenntarthatóságnak sokkal inkább ezt a formáját tartják szem előtt, mintsem a hosszú távú szempontokra is kiterjedő kulturális fenntarthatóságot.

A szerzői jog esetében azokat a versenyspecifikus vonásokat említem meg, amelyek Tattay szerint nagyban befolyásolják a szerzői jog versenyképességének lehetőségeit. ${ }^{78}$ A szerzői jogot eszerint alacsony jövedelemteremtő képesség jellemzi - a szabad felhasználási módok és a szerzői jog szociális funkciója jelentősen a versenyképesség ellenében ható tényezők; a jogi szabályozás fogyatékosságokkal küzd - uniós szinten hiányzik egy általános, átfogó szerzői jogi szabályozás, a meglévő jogszabályok csak egyes területekre térnek ki, és jellemző a soft law;

${ }^{75}$ BoYTHA György: A szerzői jog iparjogvédelmi és versenyjogi határterületei. Jogtudományi Közlöny, 1969/2-3, 109.

${ }^{76}$ Lásd A Bizottság közleménye az Európai Parlamentnek, a Tanácsnak, az Európai Gazdasági és Szociális Bizottságnak és a Régiók Bizottságának. A következő lépések Európa fenntartható jövőjéért. Európai fellépés a fenntarthatóságért, 2016, $\operatorname{COM(2016)~739.~https://eur-lex.europa.eu/legal-content/HU/TXT/PDF/?uri=CE~}$ LEX:52016DC0739\&from=HU (2021.05.16.).

77 GóR Arnold: A fenntarthatóság és a versenyképesség közös pontjai, kölcsönhatásai. Gazdálkodás, 2013/2, 174-177. (https://doi.org/10.22004/ag.econ.166595)

78 TATTAY (2016): i. m., 247-254. 
jellemző vonás az állami szerepvállalás - a kultúrpolitikai, mecenatúra-jellegű állami beavatkozáson túlmenően például a közös jogkezelés szabályozása vagy az innovációt és kreativitást ösztönző jogi szabályozás említhető e körben; különösen az audiovizuális szektort jellemzi a rohamos technikai fejlődés - ennek következtében megváltozik az audiovizuális értéklánc, nagy hatással van a terület fejlődésére az egyre nagyobb méreteket öltő digitalizálási folyamat, teret nyer a szerzői alkotások ipari felhasználása, egyre inkább elterjednek a felhasználók által létrehozott tartalmak valamint a hagyományos müsorszolgáltatás és az internet fokozatos konvergenciája; a közös jogkezelésben monopolhelyzet áll fenn.

A szerzői jognak ösztönző hatása lehet a versenyképességre. Mivel azonban meglehetősen nemzeti jellegű a szabályozás, nemzetközi szinten viszonylag későn, az európai integráció elörehaladott szakaszaiban ismerték csak fel a kreatív iparágak és ezzel együtt a szerzői jog szerepét. Ezt a szerepet a szerzői jog a kulturális értékek cserefolyamatában katalizátorként, a befektetéseket ösztönző jogi környezet fontos részeként tölti be. ${ }^{79}$

A szerzői jog ebbéli szerepének felismerése nagyjából párhuzamosan zajlik nemzetközi és európai uniós szinten. A WIPO 2003-ban jelentette meg első módszertani útmutatóját, amely a szerzői jogi ágazatok gazdasági súlyának egységes nemzetközi mérésére, elemzésére, összehasonlítására hivatott. ${ }^{80} \mathrm{~A} 2010$-es években nemzetközi szinten további jelentős tanulmányok, felmérések készültek a szerzői jog és a gazdaság kapcsolata, illetve a szerzői jogból származó jövedelem jelentőségének tárgyában, amelyek megerősítették, hogy a szerzői jogi ágazatok számottevően hozzájárulnak a gazdaság növekedéséhez és a foglalkoztatás bővüléséhez. ${ }^{81}$

A fentiekkel nagyjából azonos időszakban az Európai Unióban is fontos dokumentumok születtek a témában. Az Európai Bizottság Belső Piaci Főigazgatóságának megbízásából 2003-ban elkészült jelentés felhívta a figyelmet a szerzői jogi ágazatoknak az európai gazdaságban betöltött szerepére. ${ }^{82} 2007$ és 2015 között négy Zöld könyvet is kiadtak a szerzői jog területén, jelezve a jogterületre irányuló figyelmet. Emellett az EU számos szerzői jogi tematikájú irányelvet fogadott el máig, tehát látványosan egyre nagyobb gazdasági jelentőséget tulajdonítanak a szerzői jogi alapú gazdasági ágazatoknak. ${ }^{83}$

A kreatív piac Josef Drexl által kidolgozott elmélete a kreativitást növelő szerzői jog piacorientált elveit írja le. A koncepció egyik iránya a szerzői művekhez való diszkriminációmentes hozzáféréssel foglalkozik - Drexl szerint határokon átnyúló,

\footnotetext{
79 TATTAY (2015): i. m., 18.

80 Guide on Surveying the Economic Contribution of the Copyright-Based Industries. WIPO, 2003. - A módszertani útmutatót a WIPO 2015-ben aktualizálta, jelenleg ez a változat irányadó.

81 „Intellectual property rights intensive industries: contribution to economic performance and employment in the European Union. Industry-Level Analysis Report. A joint project between the European Patent Office and the Office for Harmonization in the Internal Market, EPO-OHIM, 2013; WIPO Studies on the Economic Contribution of the Copyright Industries - Overwiew. World Intellectual Property Organization (WIPO), Geneva, 2014.

82 Picard, Robert G.-Toivonen, Timo E.-Grönlund, Mikko: The Contribution of Copyright and Related Rights to the European Economy. Final Report. 2003.

83 TATTAY (2016): i. m., 227-228.
} 
multiterritoriális engedélyezési rendszer kialakítására lenne szükség -, másik iránya pedig a szerzői jogi ágazat piaci viszonyaiba való beavatkozást tárgyalja, mégpedig a beruházásokat ösztönzi észszerü kockázatvállalás alapján - ennek körében az állami beavatkozást csak olyan esetekben tartja elfogadhatónak, amikor a versenyt a szellemi tulajdon szükséges védelmét meghaladó mértékben korlátozó felhasználásról van szó. ${ }^{84} \mathrm{~A}$ diszkriminációmentes hozzáférés kiindulópontját a közös jogkezelő szervezetek monopolhelyzete képezi. Emiatt elvárásként fogalmazza meg, hogy a közös jogkezelők ne csak az általuk jövedelmezőnek minősített műveket fogadják be, hanem minden mühöz ugyanolyan hozzáférést biztosítsanak, mert ez járul hozzá leginkább a közérdek, a fogyasztók érdekeinek kielégítéséhez, és a kulturális sokféleség megvalósulásához. A fogyasztói érdekek kiegyenlített kielégítését preferálja ez az elmélet. ${ }^{85}$

A versenyképességi szempontok tehát közvetve visszakapcsolódnak a szerzői jog kívánt egyensúlyának kialakításához az egyes érdekek érvényesülési lehetőségeinek biztosítása révén, és így a fenntarthatóság fontos vonatkozását képezik a szerzői jogban. Láttuk azonban, hogy a versenyképességi oldalról történő megközelítés sokkal inkább a gazdasági szempontokat helyezi előtérbe a kulturális szempontokkal szemben. A szerzői jogi szabályozás illetve a versenyképességre való törekvés ugyan pozitív hatással van a kultúra térnyerésére, a kulturális sokszínüség, a kulturális fenntarthatóság igazi, hosszú távú szempontjait nem képes érvényesíteni.

\section{3. Összegzés}

A szerzői jog fenntarthatóságához vezető utakat több szempont vizsgálatával vázoltam fel. Áttekintettem a kulturális fenntarthatóság vonatkozásait, majd a szerzői jog kívánatos egyensúlyának kialakítása terén felmerülő kihívásokkal foglalkoztam. A kihívások egy központi kérdés köré rendezhetők, mégpedig hogy a szerzői jogi szabályozás mennyire legyen erős vagy éppen gyenge. Akár az érintett érdekcsoportok érdekeit, akár a szabad felhasználási módokat vagy éppen a személyhez füződő jogok és vagyoni jogok kapcsolatát, esetleg a szerzői jogdíjak kérdését szemléljük, mindegyik aspektus a szabályozás erősségével fonódik össze. A kérdés minden korban újra és újra felmerül, az egyensúly meglehetősen törékeny, és gyakran teljesen fel is borul. Ezt azonban nem értékelhetjük egyértelműen negatívumként, hiszen az újabb kihívások hoznak mindig újabb megoldásokat is, és ez jelenti a fejlődés útját. Ahogyan más jogágak fejlődése sem lenne elképzelhető csupán a jogászok szellemi munkájának következményeként, úgy a szerzői jogban is az újabb problémás helyzetek, egyensúlyt nélkülöző állapotok hívnak életre új jogi szabályozást. Napjainkban pedig éppen a fenntarthatóság problémaköre jelenti az egyik legnagyobb kihívást a szerzői jogban (is).

${ }^{84}$ TATTAY (2016): i. m., 266-268.

85 GRAD-GYenge-SARKADY: i. m., 52. 
Láttuk, hogy a hagyományos filozófiai háttér ma már nem elegendő a szerzői jog megalapozásához, a 21. században a szerzői jognak is alkalmazkodnia kell az alapvető emberi jogok rendszeréhez, és emellett az emberi jogi rezsimnek is határozottan állást kell foglalnia a szerzői jognak az emberi jogok körében elfoglalt helye kapcsán. A szerzői jog egyensúlyát ezen felül a személyhez füződő jogok és a vagyoni jogok külön egyensúlyának kialakítása révén lehet csak elérni. Ami mára mindenképpen világossá vált: a szerzői vagyoni jogok és személyhez füződő jogok egymástól elkülönítetten nem, csak egymásra tekintettel, egymással párhuzamosan fejlődhetnek, így járulhatnak hozzá egy holisztikus szerzői jog kialakulásához. Örvendetes, hogy mindezt már nemzetközi és európai uniós szinten is felismerték. A megvalósítást tekintve azonban nem lehetünk még teljesen nyugodtak: a korábban a jogfejlődés motorját jelentő nemzetközi jog mára igen statikussá vált, a status quo-tól történő elmozdulás nagyon lassú folyamatnak látszik, az utóbbi időben nem született a szerzői jog terén nemzetközi szerződés, inkább csak soft law jellegű dokumentumok jellemzik a nemzetközi szerzői jogi jogalkotást. ${ }^{86}$ Az európai uniós szerzői jogi jogharmonizációs folyamatban is még csak törekvésként jelennek meg a fenntarthatóság szempontjai, a konkrét rendelkezések még nem születtek meg, vagy csak kezdetlegesen szerepelnek például a hivatkozott 2019/790/EU irányelvben. Lassú átalakulás zajlik, de biztató jel, hogy legalább a törekvések már határozottan megfogalmazódtak.

A napjainkban megfigyelhető törekvés a szerzői jogi ágazatok versenyképességének növelésére, illetve általában a gazdasági növekedés szempontjai kapcsán látható, hogy azok sok esetben csak a fenntarthatóság kárára valósíthatók meg. Ebből pedig az következik, hogy a fenntarthatóság érvényesüléséhez be kell látni, hogy a növekedés nem folytatható a végtelenségig.

Látható, hogy a szerzői jog leginkább akkor képes megfelelni a fenntarthatóság követelményeinek, amikor a fenntarthatóság kulturális pillérét szolgálja. A gazdasági pillér kapcsán azonban konfliktusokkal küzd - ahogyan azt a versenyképesség vizsgálata körében láttuk.

Általánosságban a tendenciák nemzetközi szinten is egy minél teljesebb körben megvalósítandó szerzői jogi jogharmonizáció irányában hatnak, amely elé azonban időről időre újabb akadályok gördülnek. A szerzői jog új egyensúlyának kialakulása napjainkban is zajlik, és bizonyos részterületeken szembetűnőbb, máshol még csekélyebb sikerek könyvelhetők el. Mégsem mondhatjuk, hogy szélmalomharc lenne a munka, mert az eredmények - ha lassan és visszafogottan is, de - látszanak: a fenntarthatósági szempontok egyre nagyobb mértékben, egyre határozottabban érvényesülnek a szerzői jogban.

\footnotetext{
86 UJHELYI Dávid: „That Escalated Quickly”, avagy a háromlépcsős teszt és a paródia kapcsolódási pontjai I. Iparjogvédelmi és Szerzői Jogi Szemle, 2019/6, 7-8.
} 